Terbit online pada laman web jurnal : http://e-journal.sastra-unes.com/index.php/JIPS

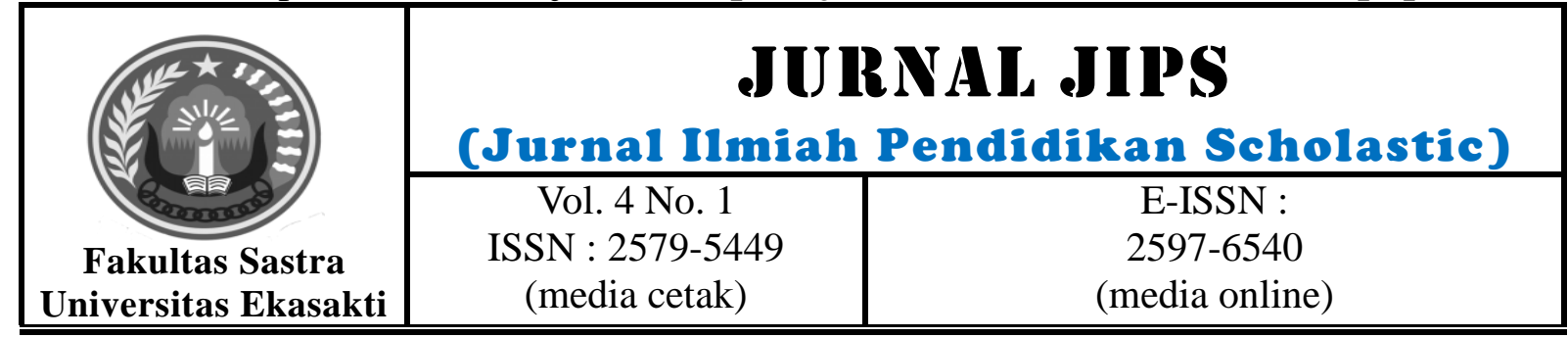

\title{
KONTRIBUSI PENGUASAAN KOSAKATA TERHADAP \\ KEMAMPUAN MENULIS KARANGAN ARGUMENTASI SISWA KELAS X MA NEGERI X KOTO SINGKARAK KABUPATEN SOLOK
}

\author{
Susanti Marisya \\ Dosen Program Studi Pendidikan Bahasa dan Sastra Indonesia \\ Universitas Ekasakti
}

\begin{abstract}
Permasalahan yang melatarbelakangi penelitian ini adalah sebagai berikut. Pertama, menulis argumentasi merupakan hal yang sulit bagi siswa. Kedua, siswa kurang berminat dalam menulis argumentasi Ketiga, siswa kurang memiliki penguasaan dalam menulis karangan argumentasi. Keempat, kurang menguasai kosakata. Berdasarkan latar belakang masalah tersebut, tujuan penelitian ini adalah mengetahui seberapa besar kontribusi penguasaan kosakata terhadap kemampuan menulis karangan argumentasi siswa kelas X MA Negeri X Koto Singkarak.Sampel penelitian ini adalah siswa kelas X MA Negeri X Koto Singkarak Kabupaten Solok dengan total sampel 40 orang siswa.

Teknik pengambilan sampel tersebut adalah sampel total. Instrumen penelitian ini berupa tes objektif penguasaan kosakata yang telah diuji validitas dan reliabilitasnya dan tes unjuk kerja menulis karangan argumentasi. Data penelitian ini berupa skor yang telah diubah ke dalam bentuk nilai. Selanjutnya, data dianalisis dengan menggunakan uji korelasi Pearson Product Moment $(P P M)$, uji korelasi ganda, uji t, uji f.Hasil penelitian ini adalah penguasaan kosakata memberikan kontribusi sebesar 18,15\% terhadap kemampuan menulis karangan argumentasi siswa.

Hasil penelitian tersebut menunjukkan bahwa penguasaan kosakata, baik secara sendirisendiri maupun bersama-sama memberikan kontribusi yang signifikan terhadap kemampuan menulis karangan argumentasi siswa kelas X MA Negeri X Koto Singkarak Kabupaten Solok. Semakin tinggi penguasaan kosakata siswa, maka semakin tinggi pula kemampuan siswa dalam menulis karangan argumentasi. Oleh karena itu, disarankan supaya guru lebih terfokus memberikan dorongan menulis dan pelatihan-pelatihan yang memungkinkan siswa memperbanyak penguasaan kosakata.
\end{abstract}

Keywords: Kosakata, Kemampuan Menulis, Argumentasi

(C) 2019Jurnal JIPS

Jurnal JIPS (Jurnal Ilmiah Pendidikan Scholastic) Vol. 4 No. 1 (2019) ISSN : 2579-5449

This work is licensed under a Creative Commons Attribution-NonCommercial 4.0 International License. 


\section{INTRODUCTION}

Salah satu aspek keterampilan berbahasa yang sulit dikuasai oleh siswa adalah keterampilan menulis. Kesulitan itu sesuai dengan pendapat Slamet dan Saddhono (2014:150) bahwa keterampilan menulis merupakan keterampilan yang sukar dan kompleks. Oleh karena itu, keterampilan menulis dikuasai oleh seseorang sesudah menguasai keterampilan berbahasa yang lain. Pembelajaran menulis seharusnya dilakukan secara rutin dan berkala agar siswa dapat terbimbing dan terbiasa menuangkan idenya dalam menulis.

Dalam Kurikulum Tingkat Satuan Pendidikan (KTSP) tahun 2006, keterampilan menulis merupakan keterampilan yang harus dikuasai siswa, yaitu menulis tulisan argumentasi, ringkasan, surat pribadi, surat dinas, deskripsi, narasi, dan eksposisi. Salah satu materi pembelajaran yang harus diajarkan kepada siswa adalah pembelajaran menulis karangan argumentasi. Pembelajaran menulis argumentasi merupakan objek yang diteliti dalam penelitian ini. Menulis argumentasi terdapat dalam kurikulum kelas $\mathrm{X}$ semester dua dengan standar kompetensi ke-12, yaitu mengungkapkan informasi melalui paragraf dan teks pidato yang kompetensi dasarnya (12.1) yaitu menulis gagasan untuk mendukung suatu pendapat dalam bentuk paragraf argumentasi.

Permasalahan yang dialami siswa dalam menulis merupakan hal yang sulit bagi siswa yaitu, siswa kurang berminat dalam menulis argumentasi karena menganggap pembelajaran menulis adalah suatu hal yang membosankan. Permasalahan ini dapat dilihat saat proses pembelajaran menulis ini,yaitu kebanyakan siswa tidak sungguh-sungguh dalam belajar. Selain itu, apabila siswa ditugaskan untuk menulis karangan cenderung siswa hanya bermain-main dalam menyelesaikan tugas yang diberikan, terkadang hanya sebagian saja dari siswa yang mengumpulkan tugas yang diberikan tersebut.

Dalam menulis karangan argumentasi, penulis hendaknya memiliki penguasaan kosakata yang baik. Penguasaan kosakata ini diperlukan agar memudahkan seseorang menuangkan idenya dalam tulisan sehingga tulisanpun menarik dan mudah untuk dipahami pembaca. Pernyataan ini dibuktikan dengan pendapat Djiwandono (1996: 42) yang menyatakan kosakata merupakan unsur penting yang digunakan dalam komunikasi lisan maupun tulisan, makna dari suatu wacana atau tulisan sebagai bentuk penggunaan bahasa sebagian besar ditentukan oleh kosakata yang digunakan dalam tulisan tersebut. Berdasarkan pendapat itu, jelaslah bahwa semakin banyak penguasaan kosakata seseorang maka semakin baik kemampuan seseorang dalam menulis.

Penguasaan kosakata yang dimiliki siswa juga mempengaruhi hasil tulisan argumentasi siswa. Siswa terlihat kurang menguasai kosakata sehingga ide yang tertuang dalam tulisan menjadi tidak menarik untuk dibaca. Permasalahan ini dibuktikan dengan adanya ketidaksesuaian kosakata yang digunakan siswa dalam karangan argumentasi, seperti terlihat dalam kalimat berikut.

Narkoba terbentuk dari
berbagai macam bahan
obat-obatan. Salah
satunya sabu-sabu dan
ganja. Narkoba
dikonsumsi dengan cara
dihisap, dimasukkan ke
dalam tubuh. Setelah
mengkonsumsi narkoba
pemakainya akan merasa
terbang dan melayang.

Sesuai dengan contoh itu, terlihat bahwa siswa kurang menguasai kosakata sehingga tidak tepat penggunaannya dalam kalimat. Hal ini dibuktikan pada kalimat pertama (kata terbentuk seharusnya diganti dengan berasal), kedua (kalimat dimasukkan ke dalam tubuh diganti dengan injeksi atau disuntikkan).

Berdasarkan uraian itu, dapat disimpulkan penguasaan kosakata memiliki hubungan dengan kemampuan menulis karangan argumentasi. Semakin banyak menguasai kosakata dan tepat dalam pemilihan kosakata, akan semakin memudahkan siswa dalam menuangkan idenya sehinga tulisan yang dihasilkan menjadi mudah dipahami oleh pembaca. 
Berdasarkan uraian dan fenomena yang telah dipaparkan itu dapat disimpulkan bahwa penelitian yang berjudul " Kontribusi Penguasaan Kosakata terhadap Kemampuan Menulis Karangan Argumentasi Siswa Kelas X MANegeri X Koto Singkarak" penting untuk dilaksanakan.

\section{RESEARCH METHOD}

Penelitian ini termasuk penelitian deskriptif dengan menggunakan pendekatan kuantitatif dan metode korelasional. Proses pengolahan data dan pendeskripsian analisis data menggunakan rumus statistik. Metode korelasional digunakan untuk menjelaskan hubungan di antara ketiga variabel yang diteliti.Arikunto (2013:313) mengungkapkan penelitian korelasi bertujuan untuk menemukan ada tidaknya hubungan dan apabila ada, berapa eratnya hubungan serta berarti atau tidak hubungan itu. Berdasarkan hubungan tersebut, akan dianalisis lebih lanjut untuk mencari besar sumbangan tiap-tiap variabel bebas (X) terhadap variabel terikat $(\mathrm{Y})$. Variabel yang ingin dicari kontribusinya adalah kontribusi penguasaan kosakata (X) terhadap kemampuan menulis karangan argumentasi (Y). Populasi dalam penelitian ini adalah semua siswa kelas X MA Negeri X Koto Singkarak Kabupaten Solok. Pemilihan kelas $\mathrm{X}$ sebagai populasi karena materi karangan argumentasi diajarkan di kelas $X$. Sementara itu, sampel penelitian ini adalah sampel total. Jadi, sampel dalam penelitian ini adalah seluruh siswa kelas X MA Negeri X Koto Singkarak yang jumlah 40orang siswa yang terdiri dari 2 kelas.

Penelitian ini menggunakan instrumen berupa tes. Tes digunakan untuk mengumpulkan data penguasaan kosa kata dan mungumpulkan data kemampuan menulis karangan argumentasi siswa. Data yang dikumpulkan dalam penelitian ini, yaitu skor penguasaan kosakata dan skor kemampuan menulis karangan argumentasi. Pengumpulan data tersebut, menggunakan instrumen berupa tes.Tes digunakan untuk mengumpulkan data penguasaan kosakata yang dibuat dalam bentuk tes objektif.

Langkah-langkah pengumpulan data dalam penelitian ini adalah sebagai berikut. Pertama, memberikan tes objektif untuk
Adapun tujuan penelitian ini adalah mengetahui adakah kontribusi penguasaan kosakata terhadap kemampuan menulis karangan argumentasi siswa kelas X MA Negeri X Koto Singkarak. mengukur tingkat penguasaan penguasaan kosakata. Kedua, siswa mengisi lembar jawaban yang telah disediakan dengan membubuhkan tanda silang pada pilihan jawaban yang di anggap paling benar. Ketiga, memberikan tes unjuk kerja untuk mengetahui kemampuan menulis karangan argumentasi. Keempat, semua lembar jawaban yang telah terkumpul diperiksa sesuai dengan aspek dan kriteria yang telah ditetapkan sebelumnya.

Data penelitian ini berupa skor penguasaan kosakata dan karangan argumentasi siswa. Data penelitian yang berupa skor diubah dalam bentuk nilai dengan menggunakan rumus Arikunto. Selanjutnya, nilai yang diperoleh di klasifikasikan dalam tabel tingkat penguasaan. Kemudian, pendeskripsian data untuk setiap variabel dilakukan perhitungan rata-rata, median, modus, standar deviasi, serta penyusunan data dalam bentuk tabel distribusi frekuensi, dan histogram. Data penelitian ini dianalisis dengan menggunakan uji korelasi sederhana dan berganda. Uji korelasi tersebut dimaksudkan untuk menguji hipotesis penelitian.

Data penelitian ini berupa nilai penguasaan kosakata dan karangan argumentasi. Sebelum data dianalisis, perlu dilakukan uji persyaratan analisis, yaitu uji normalitas, uji homogenitas, dan uji linieritas. Selanjutnya, dilakukan pengujian hipotesis penelitian ini yaitu dengan cara mengkorelasikan antara variabel bebas penguasaan kosakata $(\mathrm{X})$ dengan variabel terikat kemampuan menulis karangan argumentasi (Y). Tujuan pengujian ini adalah untuk mengetahui signifikan atau tidaknya kontribusi masing-masing variabel bebas (X) terhadap variabel terikat (Y). Dalam mengkorelasikan variabel bebas (X) dengan variabel terikat $(\mathrm{Y})$, digunakan uji korelasi Pearson Product Moment (PPM). Setelah itu, untuk mengetahui besar kontribusi variabel bebas 
(X) terhadap variabel terikat (Y), digunakan rumus koefisien determinan. Untuk mengetahui signifikan kontribusi variabel bebas (X) terhadap variabel terikat (Y), dilakukan uji signifikan. Selanjutnya, mencari nilai $t_{\text {tabel }}$ menggunakan ketentuan tingkat kesalahan $(\alpha)=0,05$ dengan derajad bebas $(d b)=n-2$. Setelah melakukan uji korelasi, dilanjutkan dengan uji regresi sederhana. Selanjutnya, dilakukan pengujian hipotesis statistik yaitu

$$
\begin{aligned}
& \mathrm{H}_{0}=\mathrm{r}_{\text {hitung }} \leq \mathrm{r}_{\text {tabel }} \\
& \mathrm{H}_{1}=\mathrm{r}_{\text {hitung }} \geq \mathrm{r}_{\text {tabel }}
\end{aligned}
$$

Keterangan:

\section{RESULTS AND DISCUSSION}

Data dalam penelitian ini dikelompokkan menjadi dua. Data kelompok pertama adalah data yang terkait dengan variabel bebas (X) dan data kelompok kedua terkait dengan variabel terikat (Y). Berikut uraiannya

\section{Penguasaan Kosakata $(\mathrm{X})$ Siswa Kelas $X$ MA Negeri $X$ Koto Singkarak Kabupaten Solok.}

Tes penguasaan kosakata terdiri atas 30 butir soal yang berbentuk tes objektif Skor maksimal yang bisa diperoleh siswa adalah 28 dan skor minimal adalah11. Data variabel penguasaan kosakata didapat dari nilai yang diperoleh setiap siswa. Berdasarkan hasil analisis data diperoleh nilai tertinggi sebesar 93 dan nilai terendah 37.Nilai rata-rata penguasaan konsep menulis sebesar 67.1, median 67, modus 57, dan standar deviasi sebesar 14.38. Berdasarkan tabel interval persentase tingkat penguasaan kosakata siswa kelas X MA Negeri X Koto Singkarak Kabupaten Solok tergolong cukup, yaitu 67,1.

Gambaran mengenai distribusi frekuensi nilai penguasaan kosakata dibuat dalam bentuk tabel distribusi frekuensi. Berdasarkan tabel distribusi frekuensi data penguasaan kosakata tersebut, dapat diketahui bahwa 6 orang siswa atau $15 \%$ dari jumlah siswa memperoleh nilai kelompok rata-rata, yaitu 67,1. Siswa yang memperoleh nilai di bawah kelas interval ratarata berjumlah 18 orang siswa atau sebesar $45 \%$, sedangkan siswa yang memperoleh nilai di atas kelas interval rata-rata berjumlah 16 orang siswa atau sebesar $40 \%$.
$\mathrm{H}_{0}=$ tidak terdapat kontribusi penguasaan kosakata yang signifikan terhadap kemampuan menulis karangan argumentasi siswa kelas X MA Negeri X Koto Singkarak Kabupaten Solok. . Hipotesis nol $\left(\mathrm{H}_{0}\right)$ diterima apabila $\mathrm{r}_{\text {hitung }} \leq \mathrm{r}_{\text {tabel }}$ pada taraf signifikan 0,05 .

$\mathrm{H}_{1}=$ terdapat kontribusi penguasaan kosakata yang signifikan terhadap kemampuan menulis karangan argumentasi siswa kelas X MA Negeri X Koto Singkarak Kabupaten Solok. Hipotesis penelitian (H1) diterima apabila $\mathrm{r}_{\text {hitung }} \geq$

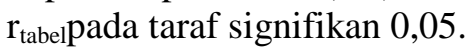

\section{Kemampuan Menulis Karangan Argumentasi (Y) Siswa Kelas X MA Negeri $X$ Koto Singkarak Kabupaten Solok.}

Tes kemampuan menulis karangan argumentasi siswa skor maksimal yang bisa diperoleh siswa adalah 85 dan skor minimal adalah 38. Data variabel kemampuan menulis karangan argumentasi didapat dari nilai yang diperoleh setiap siswa. Berdasarkan hasil analisis data diperoleh nilai tertinggi sebesar 89 dan nilai terendah 40. Nilai rata-rata kemampuan menulis karangan argumentasi sebesar 67.18, median 68, modus 65, dan standar deviasi sebesar 11,86. Berdasarkan tabel interval persentase tingkat kemampuan menulis karangan argumentasi siswa kelas X MA Negeri $X$ Koto Singkarak Kabupaten Solok tergolong cukup, yaitu sebesar 67,18. Gambaran mengenai distribusi frekuensi nilai kemampuan menulis karangan argumentasi dibuat dalam bentuk tabel distribusi frekuensi. Berdasarkan tabel distribusi frekuensi data kemampuan menulis karangan argumentasi tersebut, dapat diketahui bahwa 15 orang siswa atau $37,5 \%$ dari jumlah siswa memperoleh nilai kelompok rata-rata, yaitu 67,18. Siswa yang memperoleh nilai di bawah kelas interval ratarata berjumlah 17 orang siswa atau sebesar $42,5 \%$, sedangkan siswa yang memperoleh nilai di atas kelas interval rata-rata berjumlah 8 orang siswa atau sebesar $20 \%$.

\section{Pengujian Persyaratan Analisis}


Sebelum data dianalisis, perlu dilakukan uji persyaratan analisis, yaitu uji normalitas, uji homogenitas, dan uji linieritas terhadap data yang diperoleh. Uji normalitas dilakukan untuk mengetahui apakah data yang dihubungkan berdistribusi normal.Uji normalitas dalam penelitian ini menggunakan rumus Chi Kuadrat $\left(x^{2}\right)$. Selanjutnya uji homogenitas dilakukan untuk mengetahui apakah data yang dibandingkan bersifat homogen atau tidak. Uji homogenitas dalam penelitian ini menggunakan uji varian terbesar dibanding varian terkecil menggunakan tabel F. Kemudian, uji linieritas dilakukan untuk mengetahui apakah data yang dihubungkan berbentuk garis linier. Berikut diuraikan ketiga pengujian persyaratan analisis tersebut.

\section{Uji Normalitas}

a. Uji normalitas Tes Penguasaan Kosakata

Berdasarkan hasil uji normalitas data di peroleh nilai $\left(x_{\text {hitung }}^{2}\right)$ sebesar 7,71 dan $\left(x^{2}{ }_{\text {tabel }}\right)$ dengan $\mathrm{db}=\mathrm{k}-6=6-3=3$ dan $\alpha=0,05$ sebesar12,59. Dari penghitungan tersebut, dapat dilihat bahwa $\left(x_{\text {hitung }}^{2}<\left(x_{\text {tabel }}^{2}\right)\right.$.Apabila $\left(x_{\text {hitung }}^{2}<\left(x_{\text {tabel }}^{2}\right)\right.$, maka data berdistribusi normal. Dengan demikian, data penguasaan kosa kata berdistribusi normal karena 7,71 $<12,592$.

b. Uji Normalitas Tes Kemampuan Menulis Karangan Argumentasi

Berdasarkan hasil uji normalitas data pada tabel tersebut, di peroleh nilai

$\left(x^{2}{ }_{\text {hitung }}\right)$ sebesar 5,77 dan $\left(x_{\text {tabel }}^{2}\right)$ dengan $\mathrm{db}=\mathrm{k}$ $6=6-3=3$ dan $\alpha=0,05$ sebesar12,59. Dari penghitungan tersebut, dapat dilihat bahwa $\left(x_{\text {hitung }}^{2}<\left(x_{\text {tabel }}^{2}\right)\right.$.Apabila $\left(x_{\text {hitung }}^{2}<\left(x_{\text {tabel }}^{2}\right)\right.$, maka data berdistribusi normal. Dengan demikian, data kemampuan menulis karangan argumentasi berdistribusi normal karena 5,77 < 12,592 .

Gambaran secara keseluruhan hasil uji normalitas kedua variabel penelitian adalah sebagai berikut.

Tabel 25. Hasil Pengujian Normalitas Data Penelitian

\begin{tabular}{|l|l|l|l|}
\hline $\begin{array}{l}\text { Variabel } \\
\text { Penelitian }\end{array}$ & $\boldsymbol{x}^{\mathbf{2}}{ }_{\text {hitung }}$ & $\boldsymbol{x}^{\mathbf{2}}{ }_{\text {tabel }}$ & $\begin{array}{l}\text { Keteranga } \\
\mathbf{n}\end{array}$ \\
\hline $\begin{array}{l}\text { Penguasaan } \\
\text { Kosakata }\end{array}$ & 7,71 & 12,592 & Normal \\
\hline $\begin{array}{l}\text { Kemampuan } \\
\text { Menulis } \\
\text { Karangan }\end{array}$ & 5,77 & 12,592 & Normal \\
\hline
\end{tabular}

\begin{tabular}{|l|l|l|l|}
\hline Argumentas & & & \\
$\mathrm{i}$ & & & \\
\hline
\end{tabular}

2. Uji homogenitas hasil tes kemampuan menulis karangan argumentasi (Y) dan penguasaan kosakata $\left(X_{2}\right)$

Hasil analisis uji homogenitas tes kemampuan menulis karangan argumentasi (Y) dan penguasaan kosakata (X) disajikan dalam bentuk tabel berikut ini.

Tabel 27. Uji Homogenitas Hasil Tes Kemampuan Menulis Karangan Argumentasi (y) dan Penguasaan Kosakata $\left(\mathbf{X}_{2}\right)$

\begin{tabular}{|c|c|c|c|c|c|c|}
\hline $\begin{array}{l}\mathbf{N} \\
\mathbf{0}\end{array}$ & $\begin{array}{c}\text { Variab } \\
\text { el }\end{array}$ & $\mathbf{N}$ & $\mathbf{S}^{2}$ & $\begin{array}{l}\mathbf{F}_{\text {hit }} \\
\text { ung }\end{array}$ & $\begin{array}{c}\mathbf{F}_{\text {ta }} \\
\text { bel }\end{array}$ & $\begin{array}{c}\text { Kete } \\
\text { rang } \\
\text { an }\end{array}$ \\
\hline 1 & $\begin{array}{l}\text { Kemam } \\
\text { puan } \\
\text { menulis } \\
\text { karanga } \\
\text { n } \\
\text { argume } \\
\text { ntasi } \\
\text { (Y) }\end{array}$ & $\begin{array}{l}4 \\
0\end{array}$ & $\begin{array}{l}140, \\
76\end{array}$ & \multirow[t]{2}{*}{$\begin{array}{l}1,4 \\
7\end{array}$} & \multirow[t]{2}{*}{$\begin{array}{l}1,7 \\
25\end{array}$} & \multirow[t]{2}{*}{$\begin{array}{l}\text { Hom } \\
\text { ogen }\end{array}$} \\
\hline 2 & $\begin{array}{l}\text { Pengua } \\
\text { saan } \\
\text { kosakat } \\
\mathrm{a}\left(\mathrm{x}_{2}\right)\end{array}$ & $\begin{array}{l}4 \\
0\end{array}$ & $\begin{array}{l}206, \\
86\end{array}$ & & & \\
\hline
\end{tabular}

Berdasarkan data pada tabel diatas, varian terbesar berada pada variabel konsep menulis, yaitu sebesar 206,86, sedangkan varian terkecil berada pada variabel kemampuan menulis karangan argumentasi, yaitu sebesar 140,76. Hasil penghitungan dari kedua data tersebut diperoleh $\mathrm{F}_{\text {hitung }}$ sebesar 1,47, sedangkan nilai $F_{\text {tabel }}$ pada taraf signifikan $\alpha=0,05$, dengan $\mathrm{db}_{\text {pembilang }}=40-1=39$ dan $\mathrm{db}_{\text {penyebut }}=40-1=39$ adalah 1,725. Kriteria homogenitas data adalah jika $F_{\text {hitung }} \leq F_{\text {tabel, }}$ maka homogen. Dengan demikian, dapat disimpulkan bahwa hasi tes kemampuan menulis karangan argumentasi (Y) dan tes penguasaan kosakata (X) mempunyai varian yang homogen karena $F_{\text {hitung }}<\mathrm{F}_{\text {tabel }}$ atau $1,47<1,725$.

\section{c. Uji linieritas untuk Variabel Kemampuan menulis karangan}


argumentasi (Y) atas Variabel penguasaan kosakata $(X)$

Berdasarkan hasil penghitungan analisis regresi sederhana terhadap variabel terikat kemampuan menulis karangan argumentasi (Y) dan variabel penguasaan kosakata $(\mathrm{X})$ diperoleh koefisien

Tabel 29. Analisis Variansi (ANOVA) untuk Uji Linieritas Regresi dan Signifikansi antara Variabel $Y$ atas $\mathbf{X}_{2}$

\begin{tabular}{|c|c|c|c|c|c|}
\hline $\begin{array}{c}\text { Sumbe } \\
\mathrm{r} \\
\text { Varian } \\
\text { si }\end{array}$ & $\begin{array}{c}\text { Dera } \\
\text { jat } \\
\text { beba } \\
\mathrm{s} \\
(\mathrm{db})\end{array}$ & $\begin{array}{c}\text { Jumla } \\
\text { h } \\
\text { kuadra } \\
\text { t (JK) }\end{array}$ & $\begin{array}{c}\text { Rata- } \\
\text { rata } \\
\text { Jumla } \\
\text { h } \\
\text { Kuadr } \\
\text { at } \\
\text { (RJK) }\end{array}$ & $\begin{array}{c}\mathrm{F}_{\text {hitu }} \\
\mathrm{ng}\end{array}$ & $\begin{array}{l}\mathrm{F}_{\mathrm{ta}} \\
\text { bel }\end{array}$ \\
\hline Total & 40 & $\begin{array}{l}17768 \\
8,9\end{array}$ & - & - & - \\
\hline $\begin{array}{l}\text { Regresi } \\
\text { (a) } \\
\text { Regresi } \\
\text { (bla) } \\
\text { Residu }\end{array}$ & $\begin{array}{l}1 \\
1 \\
48\end{array}$ & $\begin{array}{l}17768 \\
8,9 \\
954,74 \\
4296,3 \\
4\end{array}$ & $\begin{array}{l}17768 \\
8,9 \\
954,74 \\
113,06\end{array}$ & $\begin{array}{l}0,3 \\
77\end{array}$ & $\begin{array}{l}2,2 \\
1\end{array}$ \\
\hline $\begin{array}{l}\text { Tuna } \\
\text { Cocok } \\
\text { (TC) } \\
\text { Kesala } \\
\text { han } \\
\text { (error) }\end{array}$ & $\begin{array}{l}18 \\
22\end{array}$ & $\begin{array}{l}924,59 \\
3371,7 \\
5\end{array}$ & $\begin{array}{l}57,79 \\
153,26\end{array}$ & & \\
\hline
\end{tabular}

Berdasarkan hasil penghitungan analisis regresi pada tabel tersebut, dapat disimpulkan bahwa bentuk hubungan antara penguasaan kosakata (X) dengan kemampuan menulis karangan argumentasi (Y) adalah linier dan signifikan. Kedua variabel tersebut dinyatakan linier karena $F_{\text {hitung }}<F_{\text {tabel }}$ dengan $\alpha=0,05$ dan $d b$ TC $20-2=18, \mathrm{db} \mathrm{E}=40-18$, yaitu $0,377<$ 2,21 .

\section{d. Pengujian Hipotesis}

Pengujian hipotesis dalam penelitian ini dilakukan dengan menggunakan uji korelasi Pearson Product Moment (PPM), uji korelasi ganda, uji t, uni f, dan koefisien determinan

Kontribusi penguasaan kosakata $(X)$ terhadap Kemampuan Menulis Karangan Argumentasi (Y)
Hipotesis yang diajukan dalam penelitian ini adalah penguasaan kosakata $(\mathrm{X})$ berkontribusi secara signifikan terhadap kemampuan menulis karangan argumentasi (Y) siswa kelas X MA Negeri X Koto Singkarak Kabupaten Solok. Pengujian hipotesis yang dilakukan adalah sebagai berikut.

$\mathrm{H}_{\mathrm{a}}=$ terdapat kontribusi penguasaan kosakata yang signifikan terhadap kemampuan menulis karangan argumentasi seswa kelas X MA Negeri $\mathrm{X}$ Koto Singkarak Kabupaten Solok.

$\mathrm{H} 0=\underset{\text { penguasaan tidak terdapat kontribusi }}{ }$ signifikan terhadap kemampuan menulis karangan argumentasi siswa kelas X MA Negeri X Koto Singkarak Kabupaten Solok.

Dalam pembuktian hipotesis tersebut, dilakukan pengujian hipotesis dengan menggunakan rumus uji korelasi Pearson Product Moment. Besar kontribusi penguasaan kosakata terhadap kemampuan menulis karangan argumentasi. Hasil penghitungan pengujian hipotesis adalah sebagai berikut.

Tabel Uji Hipotesis

\begin{tabular}{|c|c|c|c|c|}
\hline \multirow{2}{*}{$\begin{array}{c}\text { Korelasi } \\
\text { antara } \\
\text { variabel }\end{array}$} & \multirow{2}{*}{$\begin{array}{l}\text { Koefisi } \\
\text { en } \\
\text { korela } \\
\text { si }\left(r_{x 2 y}\right)\end{array}$} & \multirow{2}{*}{$\begin{array}{c}\text { Koefisie } \\
\text { n } \\
\text { Determi } \\
\text { nasi } \\
\text { (KP) }\end{array}$} & \multirow{2}{*}{$\begin{array}{c}\mathbf{t}_{\text {hitu }} \\
\text { ng }\end{array}$} & $\mathbf{t}_{\text {tabel }}$ \\
\hline & & & & $\begin{array}{c}\alpha= \\
0,05\end{array}$ \\
\hline $\begin{array}{l}\text { Penguas } \\
\text { aan } \\
\text { kosakata } \\
(\mathrm{X}) \\
\text { terhadap } \\
\text { kemamp } \\
\text { uan } \\
\text { menulis } \\
\text { karangan } \\
\text { argumen } \\
\text { tasi }(\mathrm{Y})\end{array}$ & 0,426 & $18,15 \%$ & $\begin{array}{l}2, \\
895\end{array}$ & $\begin{array}{l}2,024 \\
39\end{array}$ \\
\hline
\end{tabular}

Berdasarkan tabel tersebut, dapat diketahui bahwa variabel penguasaan kosakata (X) berkorelasi dengan variabel kemampuan menulis karangan argumentasi (Y) sebesar 0,426. Berdasarkan interpretasi koefisien korelasi nilai $r$, maka korelasi penguasaan kosakata dengan kemampuan menulis karangan argumentasi tergolong cukup. Selanjutnya, besar sumbangan

Jurnal JIPS (Jurnal Ilmiah Pendidikan Scholastic) Vol. 4 No. 1 (2019) ISSN : 2579-5449

This work is licensed under a Creative Commons Attribution-NonCommercial 4.0 International License. 
variabel penguasaan kosakata (X) terhadap kemampuan menulis karangan argumentasi (Y) adalah sebesar $18,15 \%$. Hal ini menunjukkan bahwa kemampuan menulis karangan argumentasi (Y) adalah sebesar $18,15 \%$ oleh penguasaan kosakata (X), sedangkan sisanya dipengaruhi oleh faktor lain. Dengan demikian, semakin tinggi penguasaan kosakata, maka semakin tinggi kemampuan menulis karangan argumentasi siswa kelas X MA Negeri X Koto Singkarak.

Dalam menguji signifikansi besar sumbangan penguasaan kosakata (X) terhadap kemampuan menulis karangan argumentasi (Y), maka dilakukan uji signifikansi dengan uji t dan membandingkan nilai $t_{\text {hitung }}$ dengan $t_{\text {tabel. Kaidah }}$ pengujiannya, jika $t_{\text {hitung }} \geq t_{\text {tabel, }}$ maka signifikan, jika $t_{\text {hitung }} \leq t_{\text {tabel }}$ maka tidak signifikan. Berdasarkan uji signifikansi dengan menggunakan uji $t$ diperoleh nilai $t_{\text {hitung }}$ sebesar 2 , 895dan $t_{\text {tabel }}$ dengan tingkat kesalahan $\alpha=0,05$ dan $\mathrm{db}=\mathrm{n}-2=40-2=38$ sebesar2, 02439, berarti $t_{\text {hitung }}>t_{\text {tabel }}$ atau 2, $895>2,02439$. Dengan demikian, $\mathrm{H}_{0}$ ditolak dan $\mathrm{H}_{\mathrm{a}}$ diterima, berarti hipotesis yang berbunyi penguasaan kosakata berkontribusi secara signifikan terhadap kemampuan menulis karaangan argumentasi siswa kelas X MA Negeri X Koto Singkarak Kabupaten Solok dapat diterima.

Selanjutnya, berdasarkan uji linieritas model regresi yang telah dilakukan dalam persyaratan anlisis terhadap pasangan data penguasaan kosakata dan kemampuan menulis karangan argumentasi diperoleh koefisien arah regresi (b) 0, 331 konstanta (a) sebesar 44,343. Dengan demikian, kontribusi penguasaan kosakata terhadap kemampuan menulis karangan argumentasi dapat dinyatakan dengan persamaan regresi $\widehat{Y}=44,343+0,331 \mathrm{X}_{2}$. Hal ini menunjukkan bahwa, jika tidak ada penguasaan kosakata pada diri siswa atau $X_{1}=0$, maka nilai kemampuan menulis karangan argumentasi telah ada sebesar 44,343. Persamaan regresi tersebut bisa digunakan untuk prediksi, yaitu apabila penguasaan kosakata siswa diperbaiki satu nilai, maka kemampuan menulis karangan argumentasi (Y) meningkat sebesar 0,331. Oleh karena itu, bila ingin meningkatkan kemampuan menulis karangan argumentasi siswa, maka penguasaan kosakata mereka harus ditingkatkan.

Berdasarkan hasil analisis data diperoleh temuan penelitian yaitu penguasaan kosakata berkontribusi secara signifikan terhadap kemampuan menulis karangan argumentasi siswa kelas X MA Negeri X Koto Singkarak Kabupaten Solok. Berdasarkan hasil penelitian di MA Negeri X Koto Singkarak Kabupaten Solok, ditemukan bahwa penguasaan kosakata memberikan kontribusi yang signifikan terhadap kemampuan menulis karangan argumentasi. Berdasarkan tabel interpretasi koefisien korelasi nilai $r$, koefisien korelasi penguasaan kosakata dengan kemampuan menulis karangan argumentasi tergolong cukup, yaitu 0,426. Selanjutnya kontribusi penguasaan kosakata terhadap kemampuan menulis karangan argumentasi diperoleh sebesar $18,15 \%$. Hal ini menunjukkan bahwa $18,15 \%$ kemampuan menulis karangan argumentasi dipengaruhi oleh penguasaan kosakata mereka, sedangkan sisanya dipengaruhi oleh variabel lain. Oleh karena itu, penguasaan kosakata harus mendapatkan perhatian yang lebih dari siswa dan guru MA Negeri X Koto Singkarak Kabupaten Solok. Kemudian, kontribusi penguasaan kosakata terhadap kemampuan menulis karangan argumentasi memiliki persamaan regresi sederhana $\hat{Y}=44,343+0,331 \mathrm{X}_{2}$ Hal ini menunjukkan bahwa pada saat penguasaan kosa belum memberikan pengaruh terhadap kemampuan menulis karangan argumentasi, nilai kemampuan menulis karangan argumentasi telah ada sebesar 44,343. Pada saat konsep menulis memberikan satu nilai, maka nilai kemampuan menulis karangan argumentasi akan berubah sebesar 44,343 + 0,331 (1). Oleh karena itu, semakin tinggi penguasaan kosakata yang dimiliki siswa, maka semakin tinggi kemampuan menulis karangan argumentasi.

Temuan penelitian ini sejalan dengan pendapat Tarigan (2011:17) menyatakan bahwa tingkatan kosakata seorang siswa merupakan indeks yang baik bagi kemampuan mentalnya dan fakta yang diterima secara umum. Selanjutnya, Atmazaki (2006:54) yang menjelaskan bahwa penguasaan kosakata dapat ditambah dengan berbagai cara, yaitu dengan mencari dan menguasai melalui kamus, baik kamus umum maupun kamus khusus, seperti kamus sinonim, kamus istilah ilmu pengetahuan, dan kamus ungkapan. Penguasaan kosakata juga bisa meningkat dengan memilih kata karena nuansa dan keluasan maknanya. 
Berdasarkan hasil penelitian dan beberapa pendapat ahli tersebut, dapat dipahami bahwa penguasaan kosakata memiliki peranan yang penting dalam menulis. Penguasaan kosakata siswa akan meningkatkan kemampuan mereka dalam menulis, dengan kata lain penguasaan kosakata yang banyak akan memudahkan siswa dalam menuangkan ide-ide dalam sebuah tulisan.

Sebagaimana pernyataan yang telah diuraikan dalam latar belakang penelitian bahwa penguasaan kosakata memiliki hubungan dengan kemampuan menulis karangan argumentasi, maka pernyataan tersebut telah dibuktikan dengan hasil penelitian. Hasil penelitian menunjukkan bahwa penguasaan kosakata memberikan kontribusi yang signifikan terhadap kemampuan menulis karangan argumentasi.
Penguasaan kosakata merupakan satu diantara sekian banyak faktor yang memberikan sumbangan terhadap kemampuan menulis karangan argumentasi siswa kelas X MA Negeri $\mathrm{X}$ Koto Singkarak Kabupaten Solok. Semakin banyak penguasaan kosakata siswa, semakin tinggi kemampuan menulis karangan argumentasi mereka. Rendahnya nilai kemampuan menulis karangan argumentasi siswa bisa ditingkatkan dengan meningkatkan penguasaan kosakata mereka.Oleh karena itu, guru harus meningkatkan penguasaan kosakata siswa agar kemampuan menulis karangan argumentasi mereka meningkat.

\section{CONCLUSION}

Berdasarkan hasil penelitian dan pembahasan yang telah dikemukakan, maka diperoleh simpulan yaitu penguasaan kosakata memberikan kontribusi yang signifikan sebesar $18,15 \%$ terhadap kemampuan menulis karangan argumentasi siswa kelas X MA Negeri X Koto Singkarak Kabupaten Solok. Temuan penelitian ini menunjukkan bahwa semakin banyak penguasaan kosakata siswa, maka semakin tinggi kemampuan menulis karangan argumentasi mereka.Hal ini disebabkan penguasaan kosakata diperlukan dalam menulis. Oleh karena itu, guru disarankan memberikan pelatihan-pelatihan yang memungkinkan siswa memperbanyak penguasaan kosakatanya sehingga memudahkan mereka dalam menulis.

Berdasarkan hasil penelitian, saran yang dapat diberikan adalah sebagai berikut. Pertama, kepada siswa kelas X MA Negeri X Koto Singkarak Kabupaten Solok.Siswa diharapkan dapat meningkatkan penguasaan kosakata mereka dengan cara rajin membaca kamus. Peningkatan penguasaan kosakata akan meningkatkan kemampuan menulis karangan argumentasi. Oleh karena itu, siswa harus meningkatkan penguasaan kosakatanya agar kemampuan menulis karangan argumentasi mereka meningkat. Kedua, kepada guru bahasa Indonesia di MA Negeri X Koto Singkarak Kabupaten Solok selalu mengajak siswa untuk melakukan kegiatan menulis dan menjadikan kegiatan menulis sebagai suatu kebutuhan. Kebiasaan menulis siswa akan meningkatkan penguasaan kosakata mereka dan memudahkan mereka dalam mengembangkan sebuah tulisan. Oleh karena itu, guru harus selalu memberikan dorongan untuk menulis dan untuk latihanlatihan yang dapat meningkatkan penguasaan kosakata siswa sehingga kemampuan menulis karangan argumentasi mereka meningkat. Ketiga, kepada peneliti selanjutnya. Peneliti selanjutnya yang ingin melakukan penelitian lanjutan, disarankan untuk meneliti variabel lain seperti minat baca dan lain-lain, yang berhubungan dengan kemampuan menulis karangan argumentasi. Berdasarkan hasil penelitian, masih ada variabel lain yang juga memberikan kontribusi terhadap kemampuan menulis karangan argumentasi. 


\section{Bibliography}

[1]Abdurrahman dan Ellya Ratna. 2003. Evaluasi Pembelajaran Bahasa dan Sastra Indonesia (Buku Ajar). Padang. Jurusan Bahasa dan Sastra Indonesia FBSS UNP.

[2]Alwi, dkk. 2008. Kamus Besar Bahasa Indonesia. Jakarta: Gramedia.

[3]Arikunto, Suharsimi. 2013. Prosedur Penelitian Suatu Pendekatan Praktik. Jakarta: Rineka Cipta.

[4]Arikunto, Suharsimi. 2012. Dasar-Dasar Evaluasi Pendidikan. Jakarta: Bumi Aksara.

[5]Atmazaki. 2006. Kiat-Kiat Mengarang dan Menyunting. Padang: Yayasan Citra Budaya Indonesia.

[6]Bungin, M Burhan.2010. Metodologi Penelitian Kuantitatif Komunikasi, Ekonomi, dan Kebijakan serta Ilmu-Ilmu Sosial lainnya. Jakarta: Kencana.

[7]Chaer, Abdul. 2007. Leksikologi \& Leksikografi Indonesia. Jakarta: Rineka Cipta.

[8]Daryulizar. 2009. “Kontribusi Minat Baca dan Motivasi Belajar terhadap Kemampuan Menulis Karangan Argumentasi Siswa Kelas VIII SMP Negeri 22 Padang”. (tesis). Padang: Program Pascasarjana Universitas Negeri Padang.

[9]Djiwanandono, Soenardi. 2011. Tes Bahasa bagi Pengajaran Bahasa. Jakarta: Indeks.

[10]Ermanto danEmidar. 2015. Bahasa Indonesia Pengembangan Kepribadian di Perguruan Tinggi. Padang: UNP press.

[11]Irianto, Agus. 2009. Statistik Konsep Dasar dan Aplikasinya. Jakarta. Kencana.

[12]Keraf, Gorys. 2004. Argumentasi dan Narasi. Jakarta: Gramedia Pustaka Utama.

[13]Komaidi, Didik. 2008. Menulis Kreatif (Teori dan Praktik). Yogyakarta: Sabda Media.

[14]Manaf, Ngusman Abdul. 2009. Sintaksis Teori dan Penerapan dalam Bahasa Indonesia. Padang: Sukabina Press.

[15]Manaf, Ngusman Abdul. 2008. Semantik Teori dan Penerapan dalam Bahasa Indonesia. Padang: Sukabina Press.
[16]Nurgiyantoro, Burhan. 2001. Penilaian dalam Pengajaran Bahasa dan Sastra. Yogyakarta: BPFE-Yogyakarta.

[17]Nurgiyantoro, Burhan. 2012. Penilaian Pembelajaran Bahasa Berbasis Kompetensi.Yogyakarta: BPFEYogyakarta.

[18]Pateda, Mansoer. 1995. Kosakata dan Pengajarannya. Flores NTT: Nusa Indah.

[19]Ratna. 2010. "Kontribusi Penguasaan Kosakata dan Kebakuan Kalimat terhadap Keterampilan Membaca Pemahaman Mahasiswa Program Studi Pendidikan Bahasa Indonesia Fakultas Bahasa Sastra dan Seni Universitas Negeri Padang”.(tesis). Padang: Program pascasarjana Universitas Negeri Padang.

[20]Riduwan. 2012. Dasar-Dasar Statistik. Bandung: Alfabeta

[21]Saddhono, Kundharu dan Slamet. 2014. Pembelajaran Keterampilan Berbahasa Indonesia. Yogyakarta: Graha Ilmu.

[22]Semi, M Atar. 2003. Menulis Efektif. Padang: Angkasa Raya.

[23]Sugiyono. 2012. Metode Penelitian Kuantitatif Kualitattif dan $R \quad \& \quad D$. Bandung: Alfabeta.

[24]Sugiyono. 2012. Metode Penelitian Kombinasi. Bandung: Alfabeta.

[25]Syaifudin, Ahmad. 2012. Pengembangan Model Pembelajaran Menulis Argumentasi Siswa SMA Melalui Dukungan ICT: Jurnal Pendidikan Bahasa dan Sastra Indinesia, (online), vol 1. No 1 (http://journal.ac.id/sju/indek.php/seloka, diakses 27 januari 2014).

[26]Tarigan, Henry Guntur. 2008. Menulis sebagai suatu Keterampilan Berbahasa. Bandung: Angkasa.

[27]Tarigan, Henry Guntur, dkk. 2011. Pengajaran Kosakata (Edisi Revisi). Bandung: Angkasa.

[28]Yuliarni. 2011. "Kontribusi Minat Baca dan Penguasaan Kalimat Efektif Terhadap Keterampilan Menulis Karangan Eksposisi Siswa Kelas XI SMA 10 Padang”. (tesis). Padang: Program Pascasarjana Universitas Negeri Padang. 